\title{
Investigation of mechanical properties of polymer impregnated concrete containing polypropylene fiber by taguchi and anova methods
}

\author{
Harun Tanyildizi (Main and Corresponding Author) \\ Department of Civil Engineering, Technology Faculty, Firat University \\ TR-23119, Elazig (Turkey) \\ htanyildizi@firat.edu.tr
}

Manuscript Code: 14118

Date of Acceptance/Reception: 22.02.2021/18.05.2020

DOI: $10.7764 /$ RDLC.20.1.52

\begin{abstract}
The mechanical properties of polymer impregnated concrete containing polypropylene fiber were statistically and experimentally examined in this study. Taguchi $L_{9}\left(3^{3}\right)$ was used in this study. The variables used for experiments were selected as the polypropylene fiber ratio $(0 \%, 1 \%$ and $2 \%)$ cement dosage $\left(300,350\right.$ and $\left.400 \mathrm{~kg} / \mathrm{m}^{3}\right)$ and curing time $(7,14$ and 28 days). After the specimens were cured at the specified curing times, they were dried at $105 \pm 5{ }^{\circ} \mathrm{C}$. Then, the monomer was impregnated to the specimens for 24 hours under atmospheric conditions. The samples for the polymerization of monomer was kept within the drying oven at $60^{\circ} \mathrm{C}$ for 6 hours. The compressive strength and ultrasonic pulse velocity tests of specimens, in which polymerization was applied, was conducted. Furthermore, the dynamic modulus of elasticity of samples was calculated using the ultrasonic pulse velocity. The Taguchi analysis found that the best values for the ultrasonic pulse velocity, dynamic modulus of elasticity and compressive strength were 28 days for curing, $1 \%$ for the polypropylene fiber percentage and $400 \mathrm{~kg} / \mathrm{m}^{3}$ for the cement dosage. The Anova analysis found that the polypropylene fiber percentage had the biggest effect on the mechanical properties of polymer impregnated concrete containing polypropylene fiber.
\end{abstract}

Keywords: polymer impregnated concrete, polypropylene fiber, mechanical properties, taguchi, anova analysis.

Introduction

The water is the most consumed material on world. The most second material is also concrete (Monteiro \& Mehta, 2006; Srubar, 2015). The improvement of durability and strength properties of the concrete was increased the popularity of fiber usage (Yılmaz, Dinç, Şengül, Akaya, \& Taşdemir, 2007). Scientists have been worked for the improvement of properties of the concrete. Thus, it was increased the use of fiber in concrete (Unterweger, Brüggemann, \& Fürst, 2014a). The most used fibers are polypropylene, carbon, steel, nylon, glass and polyvinyl-alcohol fibers. It is known in literature that the fibers increase the strength properties such as splitting tensile strength, bond strength, flexural strength, ductility and toughness (Czigány, 2006; Deák, Czigány, Tamás, \& Németh, 2010; Li, 2009; Matkó et al., 2003; Sobczak, Brüggemann, \& Putz, 2013; Unterweger, Brüggemann, \& Fürst, 2014b). If polypropylene fibers are used in the concrete, the micro and macro-cracks on the surface of concrete shows the decrease (Ezziane, Kadri, Molez, Jauberthie, \& Belhacen, 2015; Grzybowski \& Shah, 1990).

Their non-polar nature is the disadvantage of polypropylene fibers (Carstens, Marais, \& Thompson, 2000). This blocks the adhesive of polypropylene fiber to concrete (López-Buendía, Romero-Sánchez, Climent, \& Guillem, 2013). Behfarnia and Behravan (2014) investigated the properties of the concrete with polypropylene fiber. This study found that the durability of concrete was increased by the polypropylene fibers. Grdic et al. (2012) investigated the abrasion resistance of polypropylene reinforced concrete and conventional concrete. If the conventional concrete compared to the polypropylene fiber reinforced concrete, they found that the polypropylene fiber reinforced concrete had higher abrasion resistance. Behfarnia et al. (2013) researched the effects of polypropylene fibers, zeolite and silica fume on concrete exposed to the magnesium sulfate.

They found that the use of polypropylene fiber causes the reduction of mass loss in concrete. Ezziane et al. (2015) investigated the properties of polypropylene fiber strengthened mortars exposed to high temperature. They found that the fibers had an uncracking effect by ensuring the distribution of liquid over pressure within the matrix in mortars subject to temperatures under $400^{\circ} \mathrm{C}$. Therefore, this effect did not occur over $500^{\circ} \mathrm{C}$. Yermak et al. (2017) examined the high strength concretes including the polypropylene fibers and steel fibers exposed to fire according to the standard ISO 834. When concrete with polypropylene fiber subjected to high temperature, the crack density decreasing the vapour and liquid pressures with melting fiber. Therefore, they said that the efficiency of polypropylene fibers improved the thermal stability of cement matrix. Malek et al. (2020) investigated the effects of recycled polypropylene fibers on the mechanical properties of concrete. 
They mentioned that the use of recycled polypropylene fibers in concrete improved the mechanical properties. Polymer impregnated concrete is being obtained by impregnating monomer to concrete. The monomer that penetrates into the thinnest capillary gaps of concrete is being polymerized at such locations. Thus, the impermeable concrete and high strength concretes are consisted (Pişkin, 2010). The high strength concrete can be produced by impregnating the polymer to concrete. The large increases in the strength of concrete using the polymer are generating (Monteny, De Belie, Yincke, Beeldens, \& Taerwe, 2001; Puy \& Dikeou, 1974).

In some studies, the durability and mechanical of concrete improve by impregnation of polymer (Auskern \& Horn, 1971; Chen, Huang, Wu, \& Chen, 2006; Chmielewska, 2008; Kadela, Kukiełka, \& Małek, 2020; Moreira, Aguiar, \& Camões, 2006; Ogawa H., Kano K., Mimura T., Nagai K., Shirai A., 2007; Shıraı A., Kano K., Nagai K., Ide K., Ogawa H., 2007; Tanyildizi, 2018b; Tanyildizi \& Şahin, 2017; Uysal, Akyuncu, Tanyildizi, Sumer, \& Yildirim, 2019; Whiting \& Kline, 1976; Yang, Shi, Creighton, \& Peterson, 2009). This current study aims to examine the influences of the polypropylene fiber, curing time and, cement dosage on the strength properties of polymer concrete.

\section{Materials}

Materials and methods

The cement, which was CEM I $42.5 \mathrm{R}$ with a specific weight $3.1 \mathrm{gr} / \mathrm{cm}^{3}$, was used for the experimental study. Furthermore, the specific surface area of cement was $3430 \mathrm{~cm}^{2} / \mathrm{gr}$. The cement properties used in experiments were given in Table 1 . In the current study, polypropylene fiber was selected a rate of $0 \%, 1 \%$ and $2 \%$ of the weight of cement. The fiber properties used in experiments were given in Table 2.

\begin{tabular}{lc}
\multicolumn{2}{c}{$\begin{array}{c}\text { Table 1. The chemical compositions of cement. (Self-Elaboration). } \\
\text { compositions }\end{array}$} \\
\hline $\mathrm{CaO}$ & (\%) \\
$\mathrm{Fe}_{2} \mathrm{O}_{3}$ & 62.94 \\
$\mathrm{Al}_{2} \mathrm{O}_{3}$ & 3.24 \\
$\mathrm{SiO}_{2}$ & 5.62 \\
$\mathrm{MgO}$ & 21.12 \\
$\mathrm{LOI}$ & 2.73 \\
\hline
\end{tabular}

Table 2. The properties of polypropylene fiber. (Self-Elaboration).

\begin{tabular}{lc}
\multicolumn{2}{c}{ Table 2. The properties of polypropylene fiber. (Self-Elaboration). } \\
\hline Thermal conductivity & Low \\
Water absorption & Nil \\
Tensile strength $(\mathrm{MPa})$ & $300-400$ \\
Burning temperature $\left({ }^{\circ} \mathrm{C}\right)$ & 160 \\
Range of melting temperature $\left({ }^{\circ} \mathrm{C}\right)$ & $\sim 4000$ \\
Elastic modulus $(\mathrm{GPA})$ & 0.91 \\
Specific gravity $\left(\mathrm{g} / \mathrm{cm}^{3}\right)$ &
\end{tabular}

\section{The design of experimental and production of specimens}

The Taguchi approach is used to decrease the number of experiments. Furthermore, it is finding the optimum levels of the experimental variables affecting the results. The most important phase in the experiment design is the selection of experimental variables that affect the experimental results (Davim, 2001; Ross, 1996). The experimental variables were selected as cement dosage, curing time and the percentage of polypropylene fiber in this study. Moreover, $\mathrm{L}_{9}\left(3^{3}\right)$ orthogonal series was selected for experimental design. The levels of parameters used in the experiments were shown in Table 3. It can be shown from this table that cement dosage $\left(300,350\right.$ and $\left.400 \mathrm{~kg} / \mathrm{m}^{3}\right)$, polypropylene fiber $(0 \%, 1 \%$ and $2 \%)$ and curing time (7, 14 and 28 days) were selected as three levels.

After designing the experiments, the mixtures were prepared according to Table 4 . While preparing the mixture, the aggregate and cement were firstly mixed for 1 minutes. Then, the polypropylene fiber was added to the mixture and mixed for another 3 minutes. In the last stage, water and super plasticizer were added and mixed for another 2 minutes. The cubes of $100 \times 100 \times 100 \mathrm{~mm}$ were cast in moulds and compacted. They removed the moulds after 24 hours. Later, they were cured under standard water conditions $\left(20 \pm 2^{\circ} \mathrm{C}\right)$ at 7,14 and 28 days. 
Table 3. The levels of the variables used for experiments. (Self-Elaboration).

\begin{tabular}{|c|c|c|c|c|c|c|c|}
\hline \multicolumn{4}{|l|}{ Variables } & Level 1 & Level 2 & \multicolumn{2}{|r|}{ Level 3} \\
\hline \multicolumn{4}{|c|}{ Curing time, $\mathrm{T}$ (days) } & 3 & 7 & \multicolumn{2}{|r|}{28} \\
\hline \multicolumn{4}{|c|}{ Polypropylene fiber percentage, P (\%) } & 0 & 1 & \multicolumn{2}{|r|}{2} \\
\hline \multicolumn{4}{|c|}{ Cement dosage, $\mathrm{D}\left(\mathrm{kg} / \mathrm{m}^{3}\right)$} & 300 & 350 & \multicolumn{2}{|r|}{400} \\
\hline $\begin{array}{l}\text { Designation } \\
\text { of mixture }\end{array}$ & $\begin{array}{l}\text { Cement } \\
\left(\mathrm{kg} / \mathrm{m}^{3}\right)\end{array}$ & W/C & $\begin{array}{c}\text { Super } \\
\text { plasticizer } \\
\left(\mathrm{kg} / \mathrm{m}^{3}\right) \\
\end{array}$ & $\begin{array}{l}\text { Polypropylene } \\
\text { fiber ratio (\%) }\end{array}$ & $\begin{array}{c}\text { Aggregates, } \\
0-3 \mathrm{~mm} \\
\left(\mathrm{~kg} / \mathrm{m}^{3}\right)\end{array}$ & $\begin{array}{c}\text { Aggregates, } \\
0-7 \mathrm{~mm} \\
\left(\mathrm{~kg} / \mathrm{m}^{3}\right)\end{array}$ & $\begin{array}{c}\text { Aggregates, } \\
7-16 \mathrm{~mm} \\
\left(\mathrm{~kg} / \mathrm{m}^{3}\right)\end{array}$ \\
\hline$S$ & 400 & 0.58 & 3.2 & 0 & 578 & 501 & 584 \\
\hline$P$ & 400 & 0.58 & 3.2 & 1 & 577 & 501 & 584 \\
\hline $\mathrm{H}$ & 400 & 0.58 & 3.2 & 2 & 573 & 496 & 579 \\
\hline
\end{tabular}

\section{Polymerization}

In this study, the samples kept in curing for 7, 14 and 28 days were ejected from the curing tank. They were then dried at $105 \pm 5{ }^{\circ} \mathrm{C}$. The vinyl acetate monomer impregnated to specimens under atmospheric conditions for 24 hours (Tanyildizi, 2018a; TANYILDIZI, 2020; Tanyildizi \& Asilturk, 2018a, 2018b). Then, the specimens were kept at $60{ }^{\circ} \mathrm{C}$ for 6 hours. Consequently, the polymer impregnated concrete was realized after this process.

\section{Ultrasonic pulse velocity and compressive strength tests}

In this current study, the ultrasonic pulse velocity (UPV) and compressive strength experiments of the samples were performed after the polymer impregnated concrete were produced. Firstly, the ultrasonic pulse velocity tests of specimens were carried out according to ASTM C597-02 (ASTM C597, 2016). The UPV approach is non-destructive testing method for concrete. This method is established on the principle of measuring the velocity of P-waves sending to concrete. The UPV measurements in concrete are made in three ways.

These are direct, indirect and semi indirect. The direct method was used in this study. In this method, the transducers were placed in the middle of opposite surfaces of the concrete. Then, the measurements were performed (Bogas, Gomes, \& Gomes, 2013). The UPV was determined using the Equation 1.

where;

$$
V=S / t
$$

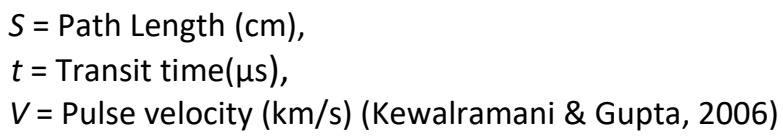

ASTM C597 (2016) was proposed Equation 2 to determine the dynamic modulus of elasticity. In the current study, the dynamic modules of elasticity of samples were determined using the Equation 2.

$$
E_{d}=\varrho \times V^{2} \times\left(\frac{(1+\mu) \times(1-2 \mu)}{(1-\mu)}\right)
$$

In equation 2, $\mathrm{E}_{\mathrm{d}}$ is the dynamic modulus of elasticity of samples (GPa). @is the density of samples $\left(\mathrm{kg} / \mathrm{m}^{3}\right) . \mu$ is poission ratio (Alfahdawi, Osman, Hamid, \& Al-Hadithi, 2018; Chandrappa \& Biligiri, 2016; Ghaffari Moghaddam, Akbarpour, \& Firouzi, 2021; Shariq, Prasad, \& Masood, 2013; Swamy \& Bouikni, 1990). Lastly, the compressive strength tests of samples were tested according to TS EN 12390-3 (TS EN 12390-3, 2019). 


\section{Compressive strength results}

The current study investigated the compressive strength of polymer concrete containing polypropylene fiber. The experimental results were given in Table 5.

Table 5. The compressive strength results of the samples. (Self-Elaboration).

\begin{tabular}{cccc}
\hline $\begin{array}{c}\text { Polypropylene fiber percentage, } \\
(\%)\end{array}$ & $\begin{array}{c}\text { Cement dosage, } \\
\left(\mathrm{kg} / \mathrm{m}^{3}\right)\end{array}$ & $\begin{array}{c}\text { Curing time, } \\
(\text { day })\end{array}$ & $\begin{array}{c}\text { Compressive Strength } \\
(\mathrm{MPa})\end{array}$ \\
\hline 0 & 300 & 3 & 29.83 \\
0 & 350 & 7 & 32.86 \\
0 & 400 & 28 & 35.61 \\
1 & 300 & 7 & 37.27 \\
1 & 350 & 28 & 39.64 \\
1 & 400 & 3 & 44.35 \\
2 & 300 & 28 & 35.49 \\
2 & 350 & 3 & 36.31 \\
2 & 400 & 7 & 39.52 \\
\hline
\end{tabular}

It must be decreased the gaps to increase the durability and mechanical strength of the concrete. If it has the gaps in concrete, it is necessary to fill the gaps. The monomer fills in the pores of concrete in polymer impregnated concrete. Then, the heating procedure is applied. The aim of this procedure is carried out the polymerization of monomer within the concrete. Because of this procedure, the strength and durability of concrete seriously improve (Bal, 1999; Sidney \& Young, 1981). The combination of polymer molecules has polar groups by physical links. This causes the strict adhesion of them to each other. Consequently, the mechanical properties of concrete are increased after this process (Tanaka, Tsuruta, \& Naitou, 2002; Yalçın, 1998). Furthermore, the durability of concrete increases also with polymer impregnation. The polymer phase constitutes an excellent bond strength between the aggregate and cement paste (Bhutta, Maruya, \& Tsuruta, 2013; Chandra \& Ohama, 1994).

In this study, Anova and Taguchi methods were selected to better analyze of results. A loss function is used in calculations. The aim of this function is calculating the deflection in between the required and experimental values. The data is found from the function. There are three different loss function. These are "higher is better", "lower is better" and "nominal is better" (Phadke, 1995; Ross, 1996; Tosun \& Tosun, 2012). Because the highest compressive strength is better, "higher is better" was selected (Atis, Tanyildizi, \& Karahan, 2009; Karahan, Tanyildizi, \& Atis, 2008; Tanyildizi, 2014; Tanyildizi, Coşkun, \& Somunkiran, 2008).

The mathematical equation of loss function Lht of LB performance characteristic was given Equation 3.

$$
L_{h t}=\frac{1}{n} \sum_{k=1}^{n} \frac{1}{y_{h t k^{2}}}
$$

where;

$L_{h t}$ is the loss function of the $h$ th performance characteristic in the $t$ th experiment $n$ the number of tests, and $y_{h t k}$ the experimental value of the $h$ th performance characteristics in the $t$ th experiment at the $k$ th test.

Then, it is exposed to a transformation for calculated the performance characteristics deviating from the required value. This is named as the S/N (Phadke, 1995; Ross, 1996; Tosun \& Tosun, 2012).

$$
n_{h t}=-10 \log \left(L_{h t}\right)
$$

The influences of the experimental variables on the compressive strength were determined by Taguchi method. The $\mathrm{S} / \mathrm{N}$ rates were shown in Figure 1. 


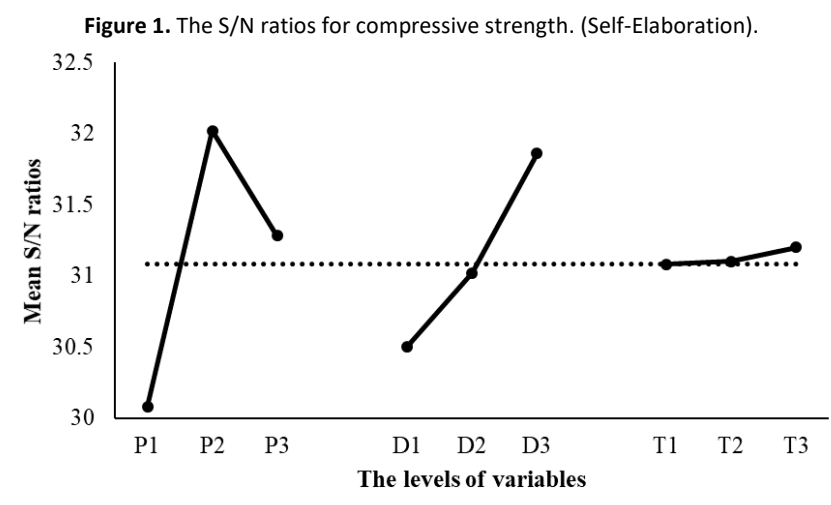

The larger $\mathrm{S} / \mathrm{N}$ provide the highest compressive strength value. It can be seen from Figure 1 that the highest compressive strength value was occurred if polypropylene fiber at a rate of $1 \%, 400 \mathrm{~kg} / \mathrm{m}^{3}$ cement dosage and the curing time of 28 days was used. The influences of the experimental variables on the compressive strength of polymer impregnated concrete were being observed in Table 6.

Table 6. The Anova results for compressive strength. (Self-Elaboration).

\begin{tabular}{lccccc}
\hline Control factor & $\begin{array}{c}\text { Degrees of } \\
\text { freedom }(f)\end{array}$ & $\begin{array}{c}\text { Sum of } \\
\text { square }\left(\mathrm{SS}_{\mathrm{A}}\right)\end{array}$ & Variance $\left(V_{A}\right)$ & $F_{A O}$ & Contribution (\%) \\
\hline Polypropylene fiber & 2 & 5.75 & 2.88 & 55.86 & 65.72 \\
percentage, (\%) & 2 & 2.82 & 1.41 & 27.41 & 32.25 \\
Cement dosage, $\left(\mathrm{kg} / \mathrm{m}^{3}\right)$ & 2 & 0.02 & 0.01 & 0.26 & 0.26 \\
Curing time, (Days) & 2 & 0.16 & 0.08 & - & 1.77 \\
Error & 8 & 8.75 & - & - & 100 \\
Total & 2 & & & & \\
\hline
\end{tabular}

It can be seen from Table 6 that the greatest influence on the compressive strength was the polypropylene fiber percentage with $65.72 \%$. The error was found as $1.77 \%$ in Anova analysis. Liu et al. (2017) used the Taguchi and Anova analysis to examine the mechanical properties of polypropylene reinforced shotcrete. They found that the fiber ratio affected the splitting tensile strength and water permeability by $74.09 \%$ and $38.53 \%$, respectively. Prasad et al. (2018) used the Taguchi method to calculate the effects of fly ash, waste foundry sand and polypropylene fiber on the compressive strength of concrete. They expressed that it was the optimum which was the use of $1 \%$ polypropylene fiber in concrete. In the current study, the similar results were obtained for compressive strength.

\section{Ultrasonic pulse velocity (UPV) results}

The UPV is used to measuring the travel period of an ultrasound sent to the concrete (Awal \& Shehu, 2015; Lin, Hsiao, Yang, \& Lin, 2011). The compressive strength is considered to be high if the value of ultrasonic pulse velocity is fast. Furthermore, the UPV can also be used for evaluating the damage of concrete subjected to some physical or chemical effects (Al-Rousan, Haddad, \& Swesi, 2015; Awal \& Shehu, 2015). The test provides an idea about the cracks or gaps in the concrete (Güneyisi, Gesollu, Booya, \& Mermerdaş, 2015). The UPV results in this study were given in Table 7.

\begin{tabular}{cccc}
\multicolumn{4}{c}{ Table 7. The UPV results of the samples. (Self-Elaboration). } \\
\hline $\begin{array}{c}\text { Polypropylene fiber } \\
\text { percentage, (\%) }\end{array}$ & $\begin{array}{c}\text { Cement dosage, } \\
\left(\mathrm{kg} / \mathrm{m}^{3}\right)\end{array}$ & $\begin{array}{c}\text { Curing time, } \\
(\text { day })\end{array}$ & $\begin{array}{c}\text { Ultrasonic pulse velocity } \\
(\mathrm{km} / \mathrm{s})\end{array}$ \\
\hline 0 & 300 & 3 & 3.61 \\
0 & 350 & 7 & 3.89 \\
0 & 400 & 28 & 4.04 \\
1 & 300 & 7 & 4.07
\end{tabular}




\begin{tabular}{lccc}
1 & 350 & 28 & 5.03 \\
1 & 400 & 3 & 4.67 \\
2 & 300 & 28 & 4.09 \\
2 & 350 & 3 & 4.08 \\
2 & 400 & 7 & 4.42 \\
\hline
\end{tabular}

Similar to the compressive strength, the Anova and Taguchi approaches were selected for the analysis of the UPV results. The $\mathrm{S} / \mathrm{N}$ rates calculated according to Table 3. The Taguchi analysis results were shown in Figure 2.

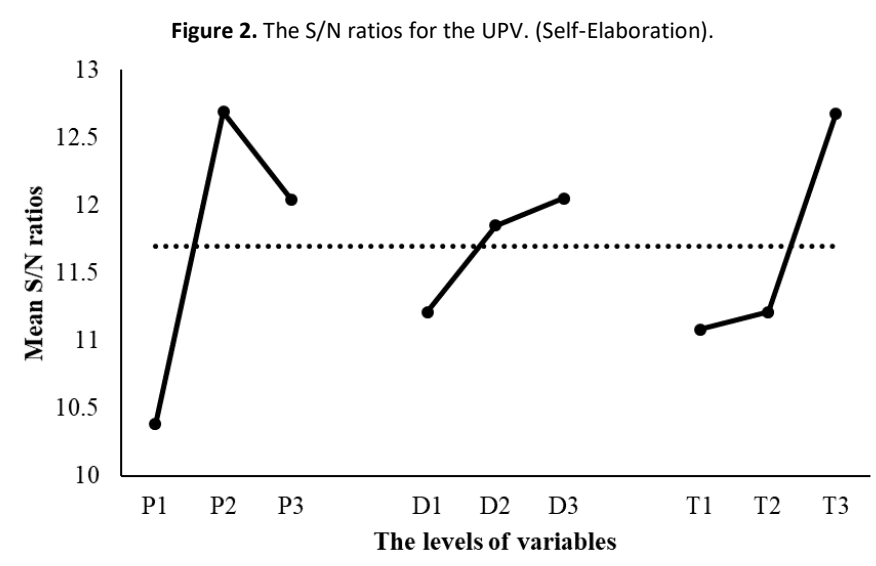

The larger S/N rates provide the best results for the UPV. As can be seen from Figure 2, the largest UPV value was obtained if the polypropylene fiber, cement dosage and curing period were used $1 \%, 400 \mathrm{~kg} / \mathrm{m}^{3}$ and 28 days, respectively. These results are similar to compressive strength. The Anova results of the UPV were shown in Table 8 .

Table 8. The Anova results for the UPV. (Self-Elaboration).

\begin{tabular}{lccccc}
\hline Control factor & $\begin{array}{c}\text { Degrees of } \\
\text { freedom }(f)\end{array}$ & $\begin{array}{c}\text { Sum of } \\
\text { square }\left(\mathrm{SS}_{\mathrm{A}}\right)\end{array}$ & Variance $\left(V_{A}\right)$ & $F_{A O}$ & Contribution (\%) \\
\hline Polypropylene fiber & 2 & 8.54 & 4.27 & 11.17 & 56.15 \\
percentage, (\%) & 2 & 1.15 & 0.58 & 1.50 & 7.54 \\
Cement dosage, $\left(\mathrm{kg} / \mathrm{m}^{3}\right)$ & 2 & 4.38 & 2.19 & 5.73 & 28.77 \\
Curing time, (Days) & 2 & 1.15 & 0.38 & - & 7.54 \\
Error & 8 & 15.22 & - & - & 100 \\
Total & & & & & \\
\hline
\end{tabular}

It can see from Table 8 that the largest effect on the UPV made the polypropylene fiber percentage with $56.15 \%$. The error was found as $7.54 \%$ in the Anova analysis. Tanyildizi (2020) examined the UPV of concrete strengthened with the polymer containing phosphazene subjected to carbonation using the Anova and Taguchi approaches. He stated that the cement content was the most important experimental parameter for the UPV. Akça et al. (2015) used the Anova approach to analyze the mechanical properties of concrete containing the recycled aggregate and the polypropylene fiber. They said that the change in fiber ratio affected the UPV. In this study, the polypropylene fiber ratio was found to be the most important parameter affecting the UPV.

\section{The dynamic modulus of elasticity}

In this study, the dynamic modulus of elasticity (DME) of the samples was calculated according to Equation 2 using the UPV of the samples. The DME results of the samples were given in Table 9.

Table 9. The DME results of the samples. (Self-Elaboration).

\begin{tabular}{cccc}
\multicolumn{5}{c}{ Table 9. The DME results of the samples. (Self-Elaboration). } \\
\hline $\begin{array}{c}\text { Polypropylene fiber percentage, } \\
(\%)\end{array}$ & $\begin{array}{c}\text { Cement dosage, } \\
\left(\mathrm{kg} / \mathrm{m}^{3}\right)\end{array}$ & $\begin{array}{c}\text { Curing time, } \\
(\text { day })\end{array}$ & $\begin{array}{c}\text { The dynamic modulus of } \\
\text { elasticity (GPa) }\end{array}$ \\
\hline 0 & 300 & 3 & 29.91 \\
0 & 350 & 7 & 34.73 \\
0 & 400 & 28 & 37.46 \\
1 & 300 & 7 & 38.02
\end{tabular}


Similar to the UPV and compressive strength, the influences of experimental parameters affecting the DME results of the samples were found by Anova analysis in this section. Also, the optimum values for the DME were determined. It was shown the $\mathrm{S} / \mathrm{N}$ rates results in Figure 3.

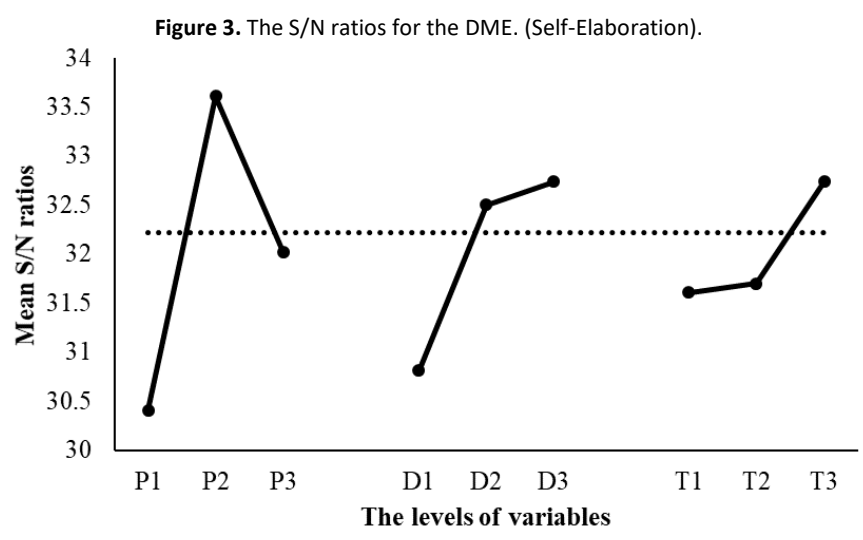

As can be seen in Figure 3, the best results for DME were obtained from samples prepared using $1 \%$ polypropylene, 400 $\mathrm{kg} / \mathrm{m}^{3}$ cement dosage and 28 days curing. The Anova results for the DME were given in Table 10.

Table 10. The Anova results for the DME. (Self-Elaboration).

\begin{tabular}{lccccc}
\hline Control factor & $\begin{array}{c}\text { Degrees of } \\
\text { freedom }(f)\end{array}$ & $\begin{array}{c}\text { Sum of } \\
\text { square }\left(\mathrm{SS}_{A}\right)\end{array}$ & Variance $\left(V_{A}\right)$ & $F_{A O}$ & Contribution (\%) \\
\hline Polypropylene fiber & 2 & 324.86 & 162.43 & 5.32 & 55.40 \\
percentage, $(\%)$ & 2 & 143.17 & 71.58 & 2.66 & 24.42 \\
Cement dosage, $\left(\mathrm{kg} / \mathrm{m}^{3}\right)$ & 2 & 57.26 & 28.63 & 17.11 & 9.77 \\
Curing time, (Days) & 2 & 61.06 & 30.53 & - & 10.41 \\
Error & 8 & 586.35 & - & - & 100 \\
Total & & & & & \\
\hline
\end{tabular}

According to Table 10, the most important experimental variable affecting the DME results was found to be the polypropylene fiber percentage. This result is similar to the results in the UPV and compressive strength. Tenza-Abril et al. (2020) used the Anova method to analyzed the UPV, DME, compressive strength of lightweight concrete. They used the aggregate type and vibration time as the experimental variables. They found that the DME of lightweight concrete was not influenced by the vibration time according to the Anova analysis. Heidarnezhad et al. (2020) examined the properties of lightweight polymer concrete using the Anova method. The polymer ratios (10-16\%) and different temperatures $\left(-15 \mathrm{C}^{\circ}-+25 \mathrm{C}^{\circ}\right)$ were selected as the experimental variables.

In the Anova analysis, they said that the polymer ratio was found to be the most important experimental parameter for the strength properties of lightweight polymer concrete. Moreover, they expressed that the higher DME was obtained at low temperatures. Zoalfakar et al. (2020) investigated the DME of concrete subjected to high temperatures using Taguchi and Anova approaches. They used $L_{25}\left(3^{5}\right)$ Taguchi arrays. They also used the steel fiber in the samples. They found that the greatest effect on the results of the DME was high temperature with $61.31 \%$. After the high temperature, they said that the most second parameter influencing the DME was the fiber percentage with $33.10 \%$. In this study, the most important parameter influencing the DME was found to be the polypropylene fiber percentage.

Conclusions

The current study investigated the effects of polypropylene fiber, curing time and cement dosage on the strength properties of polymer impregnated concrete. The Taguchi approach was used to reduce the experiment numbers in the 
experimental study. Furthermore, the optimum levels of the experimental variables were found by using the Taguchi method. This method showed that the optimum DME, UPV and compressive strength were obtained from the specimens which was used $1 \%$ polypropylene fiber, $400 \mathrm{~kg} / \mathrm{m}^{3}$ cement dosage and 28 curing days. The Anova analysis was determined the effects of the selected parameters on the experimental results. The Anova analysis found that the polypropylene fiber percentage was the most important parameter influencing the results of compressive strength, UPV and DME. The errors were obtained at low level.

References

Akça, K. I. R., Çakir, Ö., \& Ipek, M. (2015). Properties of polypropylene fiber reinforced concrete using recycled aggregates. Construction and Building Materials, 98, 620-630. https://doi.org/10.1016/j.conbuildmat.2015.08.133

Al-Rousan, R. Z., Haddad, R. H., \& Swesi, A. O. (2015). Repair of shear-deficient normal weight concrete beams damaged by thermal shock using advanced composite materials. Composites Part B: Engineering, 70, 20-34. https://doi.org/10.1016/j.compositesb.2014.10.032

Alfahdawi, I. H., Osman, S. A., Hamid, R., \& Al-Hadithi, A. I. (2018). Modulus of elasticity and ultrasonic pulse velocity of concrete containing polyethylene terephthalate (pet) waste heated to high temperature. Journal of Engineering Science and Technology, 13(11), 3577-3592.

ASTM C597. (2016). Standard Test Method for Pulse Velocity Through Concrete. American Society for Testing and Materials, West Conshohocken, PA, USA.

Atis, C. D., Tanyildizi, H., \& Karahan, O. (2009). Statistical analysis for strength properties of polypropylene-fibre- reinforced fly ash concrete. Magazine of Concrete Research, 61(7), 557-566. https://doi.org/10.1680/macr.2007.00033

Auskern, A., \& Horn, W. (1971). Some properties of polymer impregnated cements and concretes. Composites, $2(4), 257$. https://doi.org/10.1016/0010-4361(71)90187-x

Awal, A. S. M. A., \& Shehu, I. A. (2015). Performance evaluation of concrete containing high volume palm oil fuel ash exposed to elevated temperature. Construction and Building Materials, 76, 214-220. https://doi.org/10.1016/j.conbuildmat.2014.12.001

Bal, H. (1999). Investigation of the usability of some polymers in mortars. MSc thesis, Firat Univ., Elazig.

Behfarnia, K., \& Behravan, A. (2014). Application of high performance polypropylene fibers in concrete lining of water tunnels. Materials and Design, 55, 274-279. https://doi.org/10.1016/j.matdes.2013.09.075

Behfarnia, K., \& Farshadfar, O. (2013). The effects of pozzolanic binders and polypropylene fibers on durability of SCC to magnesium sulfate attack. Construction and Building Materials, 38, 64-71. https://doi.org/10.1016/j.conbuildmat.2012.08.035

Bhutta, M. A. R., Maruya, T., \& Tsuruta, K. (2013). Use of polymer-impregnated concrete permanent form in marine environment: 10-year outdoor exposure in Saudi Arabia. Construction and Building Materials, 43, 50-57. https://doi.org/10.1016/j.conbuildmat.2013.01.028

Bogas, J. A., Gomes, M. G., \& Gomes, A. (2013). Compressive strength evaluation of structural lightweight concrete by non-destructive ultrasonic pulse velocity method. Ultrasonics, 53(5), 962-972. https://doi.org/10.1016/j.ultras.2012.12.012

Carstens, P. A. B., Marais, S. A., \& Thompson, C. J. (2000). Improved and novel surface fluorinated products. Journal of Fluorine Chemistry, 104(1), 97107. https://doi.org/10.1016/S0022-1139(00)00232-3

Chandra, S., \& Ohama, Y. (1994). Polymers in concrete. United States: CRC press. Available on: https://books.google.com/books?hl=tr\&lr=\&id=QtiXvpoc4SEC\&oi=fnd\&pg=PA1\&dq=polymers+in+concrete\&ots=fNZLcA48LX\&sig=V0_LHO5ZO WwEwTq-VjdhrlDf61o

Chandrappa, A. K., \& Biligiri, K. P. (2016). Influence of mix parameters on pore properties and modulus of pervious concrete: an application of ultrasonic pulse velocity. Materials and Structures/Materiaux et Constructions, 49(12), 5255-5271. https://doi.org/10.1617/s11527-016-0858-

Chen, C. H., Huang, R., Wu, J. K., \& Chen, C. H. (2006). Influence of soaking and polymerization conditions on the properties of polymer concrete. Construction and Building Materials, 20(9), 706-712. https://doi.org/10.1016/j.conbuildmat.2005.02.003

Chmielewska, B. (2008). Adhesion Strength and Other Mechanical Properties of SBR Modified Concrete. International Journal of Concrete Structures and Materials, 2(1), 3-8. https://doi.org/10.4334/ijcsm.2008.2.1.003

Czigány, T. (2006). Special manufacturing and characteristics of basalt fiber reinforced hybrid polypropylene composites: Mechanical properties and acoustic emission study. Composites Science and Technology, 66(16), 3210-3220. https://doi.org/10.1016/j.compscitech.2005.07.007

Davim, J. P. (2001). A note on the determination of optimal cutting conditions for surface finish obtained in turning using design of experiments. Journal of Materials Processing Technology, 116(2-3), 305-308. https://doi.org/10.1016/S0924-0136(01)01063-9

Deák, T., Czigány, T., Tamás, P., \& Németh, C. (2010). Enhancement of interfacial properties of basalt fiber reinforced nylon 6 matrix composites with silane coupling agents. Express Polymer Letters, 4(10), 590-598. https://doi.org/10.3144/expresspolymlett.2010.74

Ezziane, M., Kadri, T., Molez, L., Jauberthie, R., \& Belhacen, A. (2015). High temperature behaviour of polypropylene fibres reinforced mortars. Fire Safety Journal, 71, 324-331. https://doi.org/10.1016/j.firesaf.2014.11.022

Ghaffari Moghaddam, F., Akbarpour, A., \& Firouzi, A. (2021). Dynamic modulus of elasticity and compressive strength evaluations of modified reactive powder concrete (MRPC) by non-destructive ultrasonic pulse velocity method. Journal of Asian Architecture and Building Engineering, 2020, 110. https://doi.org/10.1080/13467581.2020.1869020 
Grdic, Z. J., Curcic, G. A. T., Ristic, N. S., \& Despotovic, I. M. (2012). Abrasion resistance of concrete micro-reinforced with polypropylene fibers. Construction and Building Materials, 27(1), 305-312. https://doi.org/10.1016/j.conbuildmat.2011.07.044

Grzybowski, M., \& Shah, S. P. (1990). Shrinkage cracking of fiber reinforced concrete, 87(2), 138-148. Available on: https://www.mendeley.com/catalogue/dead6889-7119-3a0c-8649-806358bebde8/

Güneyisi, E., Gesollu, M., Booya, E., \& Mermerdaş, K. (2015). Strength and permeability properties of self-compacting concrete with cold bonded fly ash lightweight aggregate. Construction and Building Materials, 74, 17-24. https://doi.org/10.1016/j.conbuildmat.2014.10.032

Heidarnezhad, F., Jafari, K., \& Ozbakkaloglu, T. (2020). Effect of polymer content and temperature on mechanical properties of lightweight polymer concrete. Construction and Building Materials, 260, 119853. https://doi.org/10.1016/j.conbuildmat.2020.119853

Kadela, M., Kukiełka, A., \& Małek, M. (2020). Characteristics of Lightweight Concrete Based on a Synthetic Polymer Foaming Agent. Materials, 13(21), 4979. https://doi.org/10.3390/ma13214979

Karahan, O., Tanyildizi, H., \& Atis, C. D. (2008). An artificial neural network approach for prediction of long-term strength properties of steel fiber reinforced concrete containing fly ash. Journal of Zhejiang University: Science A, 9(11), 1514-1523. https://doi.org/10.1631/jzus.A0720136

Kewalramani, M. A., \& Gupta, R. (2006). Concrete compressive strength prediction using ultrasonic pulse velocity through artificial neural networks. Automation in Construction, 15(3), 374-379. https://doi.org/10.1016/j.autcon.2005.07.003

$\mathrm{Li}, \mathrm{J}$. (2009). The research on the interfacial compatibility of polypropylene composite filled with surface treated carbon fiber. Applied Surface Science, 255(20), 8682-8684. https://doi.org/10.1016/j.apsusc.2009.06.053

Lin, Y., Hsiao, C., Yang, H., \& Lin, Y. F. (2011). The effect of post-fire-curing on strengthvelocity relationship for nondestructive assessment of firedamaged concrete strength. Fire Safety Journal, 46(4), 178-185. https://doi.org/10.1016/j.firesaf.2011.01.006

Liu, G., Cheng, W., \& Chen, L. (2017). Investigating and optimizing the mix proportion of pumping wet-mix shotcrete with polypropylene fiber. Construction and Building Materials, 150, 14-23. https://doi.org/10.1016/j.conbuildmat.2017.05.169

López-Buendía, A. M., Romero-Sánchez, M. D., Climent, V., \& Guillem, C. (2013). Surface treated polypropylene (PP) fibres for reinforced concrete. Cement and Concrete Research, 54, 29-35. https://doi.org/10.1016/j.cemconres.2013.08.004

Małek, M., Jackowski, M., Łasica, W., \& Kadela, M. (2020). Characteristics of recycled polypropylene fibers as an addition to concrete fabrication based on portland cement. Materials, 13(8), 1827. https://doi.org/10.3390/MA13081827

Matkó, S., Anna, P., Marosi, G., Szép, A., Keszei, S., Czigány, T., \& Pölöskei, K. (2003). Use of Reactive Surfactants in Basalt Fiber Reinforced Polypropylene Composites. In Macromolecular Symposia (Vol. 202, pp. 255-268). Weinheim: WILEY-VCH Verlag. https://doi.org/10.1002/masy.200351222

Monteiro, P. J. M., \& Mehta, P. K. (2006). Concrete: Microstructure, Properties and Materials | Request PDF (Mc Graw Hill). Available on: https://www.researchgate.net/publication/263351386_Concrete_Microstructure_Properties_and_Materials

Monteny, J., De Belie, N., Yincke, E., Beeldens, A., \& Taerwe, L. (2001). Simulation of corrosion in sewer systems by laboratory testing. In Proceedings - fib-Symposium on Concrete and Environment 2001 (pp. 91-92). Deutscher Beton und Bautechnik Verein E.V (German Society for Concrete and Construction Technology).

Moreira, P. M., Aguiar, J. B., \& Camões, A. (2006). Systems for superficial protection of concretes. In ISPIC 2006 International Symposium on Polymers in Concrete. Guimarães. Available on: https://repositorium.sdum.uminho.pt/handle/1822/6141

Ogawa H., Kano K., Mimura T., Nagai K., Shirai A., O. Y. (2007). Durability Performance of Barrier Penetrants on Concrete Surfaces. In 12th International Congress on Polymers in Concrete (pp. 373-382). Chuncheon- Korea. Available on: https://scholar.google.com/scholar?hl=tr\&as_sdt=0\%2C5\&q=Durability+Performance+of+Barrier+Penetrants+on+Concrete+Surfaces\&btnG=

Phadke, M. (1995). Quality Engineering Using Robust Design. Prentice Hall International.

Pişkin, A. (2010). Usability of Glass Powder in Polymer Concrete. Sakarya university.

Prasad, V. D., Prakash, E. L., Abishek, M., Dev, K. U., \& Kiran, C. S. (2018). Study on concrete containing Waste Foundry Sand, Fly Ash and Polypropylene fibre using Taguchi Method. Materials Today: Proceedings, 5(11), 23964-23973. https://doi.org/10.1016/j.matpr.2018.10.189

Puy, G. W. D., \& Dikeou, J. T. (1974). Polymer in concrete. American Concrete Institute. Available on https://scholar.google.com/scholar?hl=tr\&as_sdt=0\%2C5\&q=Puy+G.W.D.\%2C+Dikeou+J.T.++\%22Polymer+in+Concrete\%22\&btnG=

Ross, P. J. (1996). Taguchi Techniques for Quality Engineering: Loss Function, Orthogonal Experiments, Parameter and Tolerance Design. Available on: https://books.google.com.tr/books?id=CiunygZ90TsC\&q=Taguchi+techniques+for+quality+engineering\&dq=Taguchi+techniques+for+quality+ engineering\&hl=tr\&sa=X\&ved=2ahUKEwjsrLrB-J3uAhWjAxAIHXNSDngQ6AEwAHoECAYQAg

Shariq, M., Prasad, J., \& Masood, A. (2013). Studies in ultrasonic pulse velocity of concrete containing GGBFS. Construction and Building Materials, 40, 944-950. https://doi.org/10.1016/j.conbuildmat.2012.11.070

Shıraı A., Kano K., Nagai K., Ide K., Ogawa H., O. Y. (2007). Basic Properties of Barrier Penetrants as Polymeric Impregnants For Concrete Surfaces. In 12th International Congress on Polymers in Concrete, (pp. 607-615). Chuncheon-Korea. Available on: https://scholar.google.com/scholar?hl=tr\&as_sdt=0\%2C5\&q=Basic+Properties+of+Barrier+Penetrants+as+Polymeric+lmpregnants+For+Concr ete+Surfaces\&btnG=

Sidney, R., \& Young, J. F. (1981). Concrete. Prentice Hall. Englewood Cliffs. Available on: https://scholar.google.com/scholar?hl=tr\&as_sdt=0\%2C5\&q=R.+Sidney\%2C+J.F.+Young+Concrete.+Prentice+Hall\%2C+Inc\%2C+Englewood+Clif fs. + New + jersey+07632+\% $281981 \% 29 . \& b t n G=$ 
Sobczak, L., Brüggemann, O., \& Putz, R. F. (2013). Polyolefin composites with natural fibers and wood-modification of the fiber/filler-matrix interaction. Journal of Applied Polymer Science, 127(1), 1-17. https://doi.org/10.1002/app.36935

Srubar, W. V. (2015). Stochastic service-life modeling of chloride-induced corrosion in recycled-aggregate concrete. Cement and Concrete Composites, 55, 103-111. https://doi.org/10.1016/j.cemconcomp.2014.09.003

Swamy, R. N., \& Bouikni, A. (1990). Some engineering properties of slag concrete as influenced by mix proportioning and curing. ACI Materials Journal, 87(3), 210-220. https://doi.org/10.14359/2148

Tanaka, T., Tsuruta, K., \& Naitou, T. Development and application of polymer impregnated concrete. In Proc of the first fib congress, Osaka, concrete structures in the 21st century 6 (pp. 347-354), Osaka, Japan, October, 2002.

Tanyildizi, H. (2014). Post-fire behavior of structural lightweight concrete designed by Taguchi method. Construction and Building Materials, 68, 565571. https://doi.org/10.1016/j.conbuildmat.2014.07.021

Tanyildizi, H. (2018a). Long-term microstructure and mechanical properties of polymer-phosphazene concrete exposed to freeze-thaw. Construction and Building Materials, 187, 1121-1129. https://doi.org/10.1016/j.conbuildmat.2018.08.068

Tanyildizi, H. (2018b). Long-term performance of the healed mortar with polymer containing phosphazene after exposed to sulfate attack. Construction and Building Materials, 167, 473-481. https://doi.org/10.1016/j.conbuildmat.2018.02.054

TANYILDIZI, H. (2020). Investigation of carbonation performance of polymer-phosphazene concrete using Taguchi optimization method. Construction and Building Materials, 273, 121673. https://doi.org/10.1016/j.conbuildmat.2020.121673

Tanyildizi, H., \& Asilturk, E. (2018a). High temperature resistance of polymer-phosphazene concrete for 365 days. Construction and Building Materials, 174, 741-748. https://doi.org/10.1016/j.conbuildmat.2018.04.078

Tanyildizi, H., \& Asilturk, E. (2018b). Performance of Phosphazene-Containing Polymer-Strengthened Concrete after Exposure to High Temperatures. Journal of Materials in Civil Engineering, 30(12), 04018329. https://doi.org/10.1061/(asce)mt.1943-5533.0002505

Tanyildizi, H., Coşkun, A., \& Somunkiran, I. (2008). An experimental investigation of bond and compressive strength of concrete with mineral admixtures at high temperatures. Arabian Journal for Science and Engineering, 33(2B), 443-449. Available on: https://www.researchgate.net/publication/268434657

Tanyildizi, H., \& Şahin, M. (2017). Taguchi optimization approach for the polypropylene fiber reinforced concrete strengthening with polymer after high temperature. Structural and Multidisciplinary Optimization, 55(2), 529-534. https://doi.org/10.1007/s00158-016-1517-z

Tenza-Abril, A. J., Benavente, D., Pla, C., Baeza-Brotons, F., Valdes-Abellan, J., \& Solak, A. M. (2020). Statistical and experimental study for determining the influence of the segregation phenomenon on physical and mechanical properties of lightweight concrete. Construction and Building Materials, 238, 117642. https://doi.org/10.1016/j.conbuildmat.2019.117642

Tosun, G., \& Tosun, N. (2012). Analysis of process parameters for porosity in porous NiTi implants. Materials and Manufacturing Processes, 27(11), 1184-1188. https://doi.org/10.1080/10426914.2011.648692

TS EN 12390-3. (2019). Testing Hardened Concrete Part 3: Compressive Strength of Test Specimens. Turkey. Available on: https://intweb.tse.org.tr/Standard/Standard/Kapak.aspx?08111805111510805110411911010405504710510212008811104311310407309910 6116122117110080075069113084

Unterweger, C., Brüggemann, O., \& Fürst, C. (2014a). Effects of different fibers on the properties of short-fiber-reinforced polypropylene composites. Composites Science and Technology, 103, 49-55. https://doi.org/10.1016/j.compscitech.2014.08.014

Unterweger, C., Brüggemann, O., \& Fürst, C. (2014b). Synthetic fibers and thermoplastic short-fiber-reinforced polymers: Properties and characterization. Polymer Composites, 35(2), 227-236. https://doi.org/10.1002/pc.22654

Uysal, M., Akyuncu, V., Tanyildizi, H., Sumer, M., \& Yildirim, H. (2019). Optimization of durability properties of concrete containing fly ash using Taguchi's approach and Anova analysis. Revista de La Construccion, 17(3), 364-382. https://doi.org/10.7764/RDLC.17.3.364

Whiting, D., \& Kline, D. E. (1976). Theoretical predictions of the elastic moduli of polymer-impregnated hardened cement paste and mortars. Journal of Applied Polymer Science, 20(12), 3353-3363. https://doi.org/10.1002/app.1976.070201215

Yalçın, F. (1998). Studies of some mechanical properties of polymer impregnated concrete. MSc thesis, Cumhuriyet Univ., Sivas.

Yang, Z., Shi, X., Creighton, A. T., \& Peterson, M. M. (2009). Effect of styrene-butadiene rubber latex on the chloride permeability and microstructure of Portland cement mortar. Construction and Building Materials, 23(6), 2283-2290. https://doi.org/10.1016/j.conbuildmat.2008.11.011

Yermak, N., Pliya, P., Beaucour, A. L., Simon, A., \& Noumowé, A. (2017). Influence of steel and/or polypropylene fibres on the behaviour of concrete at high temperature: Spalling, transfer and mechanical properties. Construction and Building Materials, 132, $240-250$. https://doi.org/10.1016/j.conbuildmat.2016.11.120

Yılmaz, B., Dinç, A., Sengül, C., Akaya, Y., \& Taşdemir, M. (2007). Effects of cement/powder ratio on workability and mechanical behaviour of SCFRCs. In International conferance on ACBM (p. 11). Lahore: ACl. Available https://scholar.google.com/scholar?hl=tr\&as_sdt=0\%2C5\&q=Effects+of+cement\%2Fpowder+ratio+on+workability+and+mechanical+behaviou $r+o f+S C F R C s \& b \operatorname{tnG}=$

Zoalfakar, S. H., Elsissy, M. A. R., \& Shaheen, Y. B. (2020). Multi-Response Optimization of Post-Fire Residual Properties of High Performance Concrete. Bulletin of the Faculty of Engineering. Mansoura University, 40(1), 83-97. 